\title{
Effectct of Changes in Land Use on Income and Expenditure Pattern of the Selected Households in North and South Direction of Raipur Town
}

\author{
Prashant Verma and Dr. K N S Banafar \\ Department of Agricultural Economics, Indira Gandhi Krishi Vishwavidyalaya Raipur-492012 (C.G.) India
}

\begin{abstract}
Agriculture forms the backbone of the Indian economy and despite concerted industrialization in the last five decades; agriculture occupies a pride of place. As the largest private enterprise in India, agriculture contributes, nearly one fourth of the national G.D.P, sustains livelihood of about two thirds of population and is the backbone of agro-based industries. It is paradoxical situation that on the one hand more production is required from the scares soil resources for meeting the demand of ever-expanding population, while on the other, cultivable areas are being shifted towards non-agricultural uses. To compute the compound growth rate of land use pattern, trend analysis was done. The double cropped area of Chhattisgarh increased from 664111 hectares in (2000-01) to 972729 hectares in (2009-10). Registering the significant growth rate of about 4.38 per cent at the 5 per cent level of probability. To know the dynamics of land transaction data were collected for the year 2005-06 before and 2009-10 present, from North and South direction at 10, 20 and 30 kilometres away from the Raipur town. The study has revealed that major shifts of land from the Agricultural to nonAgricultural uses. The overall income from non-farm and off-farm were increased in terms of the total income of households. However the share of farm income was decreased in terms of overall income of the households at present, Major consequences pertaining to land sale has to be found gambling and addiction of alcoholisms (63.33), loan repayments (21.67), got higher price of land (38.33), distress sale (15.00) per cent. The study suggested that there are great scope for further extension of area of land under cultivation, as the existence of 17.29 per cent of total geographical area is under fallow and cultivable wasteland this can be brought under cultivation in Raipur and Durg district of Chhattisgarh. It is also suggested that government and farmers agricultural land should not be transferred in to the non-Agricultural uses.
\end{abstract}

\section{Introduction}

Agriculture is a land based activity and as such land and water have been the basic elements of lifesupport system and an important resource for the economic life of a majority of people in the world. The way people handle and use land resource is decisive for their social and economic well being as well as for the sustained quality of land resources. India, with only 2.3 per cent of world's total land area supports 18 per cent of human and 15 per cent of livestock population in the world. According to the National Remote Sensing Agency's (NRSA) report, there are 75.5 million hectares of waste land in the country of which around 58 million hectares are treatable and can be brought into productive levels through appropriate measures. However the per capita arable land in the country is only is only 0.15 hectare, which is expected to come down to nearly 0.08 hectare by 2025 (Kanda, 2007). It is paradoxical situation that on the one hand more production is required from the scares soil resources for meeting the demand of ever- expanding population, while on the other; cultivable areas are being shifted towards non-agricultural uses. India has experienced a considerable shift under different land use classes during post independence period. Land uses a highly dynamic process. In light of the above, the non-farm employment has, in recent times, assumed added importance in economic development (Rao, 1995). This sector can play a positive role in removal of poverty, generation of employment and decentralization of urbanization. It also facilitates structural transformation and provides non- food goods and services to the rural people. Hence, promotion of non-farm employment in rural area itself seems to be the best option for enhancing the level of living of the rural people. A few studies have been conducted in different parts of India to estimate the extent of land transaction, demand and supply relationship, effect of land markets, legal dimension of land transactions and policy implications, However, such research inputs are inadequately available in newly born state of Chhattisgarh, where land transaction have been taking place at a rapid pace on the periphery of the big cities (Marothia et al, 1991;1995). A large number of land hungers have become actively engaged in the villages located on the periphery of Raipur city- the capital of Chhattisgarh state, to purchase prime agricultural land. The problem is more serious in the villages which are located along the national highway. In view of fast emerging land markets after the formation of the state, it is imperative to understand the role of market and non market forces in transactions of prime agricultural land for non 
agricultural uses and transactions within the agricultural sector. In view of the above, this study was undertaken to provide evidence towards this facts and show how urbanization can influence the income and employment of rural people through their farm, off-farm and non-farm activities.

\section{Material and Methods}

The present study was conducted in Raipur district of Chhattisgarh. The study area was selected on the basis of stratified random sampling. One village from North and South directions of Raipur towns was considered, $10 \mathrm{~km}$ (kilometres), $20 \mathrm{~km}$. and $30 \mathrm{~km}$. and from one village only five farmers were selected purposively. Selection of respondents was on the basis of their land sale, after formation of state of the Chhattisgarh i. e. 2004-05 for before and 2009-10 for present, in all 30 farmers were selected for present study. The primary data from the farmers were collected through personal interview with the help of well prepared questionnaire and schedule. Data include information regarding the land utilization, income and employment pattern.

III. Results and Discussion

Table 1: Land use Pattern of the Sampled Households

\begin{tabular}{|c|c|c|c|c|c|}
\hline S. No. & Particulars & Small & Medium & Large & Average \\
\hline 1 & Total owned area & $\begin{array}{c}1.81 \\
(96.79)\end{array}$ & $\begin{array}{c}3.22 \\
(100)\end{array}$ & $\begin{array}{c}4.93 \\
(98.18)\end{array}$ & $\begin{array}{c}3.21 \\
(98.44)\end{array}$ \\
\hline 2 & Leased-in land & $\begin{array}{c}0.06 \\
(3.21) \\
\end{array}$ & & $\begin{array}{c}0.08 \\
(1.62) \\
\end{array}$ & $\begin{array}{c}0.04 \\
(1.56) \\
\end{array}$ \\
\hline 3 & Leased-out land & - & - & - & - \\
\hline 4 & Total cultivated area & $\begin{array}{c}1.87 \\
(100)\end{array}$ & $\begin{array}{c}3.22 \\
(100) \\
\end{array}$ & $\begin{array}{c}5.01 \\
(100) \\
\end{array}$ & $\begin{array}{c}3.25 \\
(100) \\
\end{array}$ \\
\hline 5 & Irrigated area & $\begin{array}{c}1.33 \\
(71.12)\end{array}$ & $\begin{array}{c}2.42 \\
(75.47)\end{array}$ & $\begin{array}{c}4.04 \\
(80.64)\end{array}$ & $\begin{array}{c}2.49 \\
(76.62)\end{array}$ \\
\hline 6 & Un-irrigated area & $\begin{array}{c}0.54 \\
(28.88)\end{array}$ & $\begin{array}{c}0.8 \\
(24.53)\end{array}$ & $\begin{array}{c}0.97 \\
(19.36)\end{array}$ & $\begin{array}{c}0.76 \\
(22.38)\end{array}$ \\
\hline
\end{tabular}

Note: Figures in the parentheses indicate the percentages to the total cultivated area.

Land use pattern of the selected households was presented given in table 1. The per farm total cultivated area was observed 1.87 hectares, 3.22 hectare, 5.01 hectare on small, medium and large farms, respectively. Overall on an average the cultivated area was to be found 3.25 hectare. It is clear from the table that the leased-in land at selected households is decreasing as the size of holding increased. It varied from 3.21 per cent at small farmers to 1.62 per cent at large farms to the total cultivated area.

\section{Income from different sources Per family per Annum (In Rs.) - North Direction:}

Income received from farm, off-farm and non-farm activities was given in table 2. Total income received by the households in farm activities was Rs.4728056.56 was in before last five year, however at present 89290.23 per family per annum, in north direction of Raipur town. The contribution of farm income to total income was declined from 66.30 to 55.24 per cent at the same time off-farm and non-farm income were increased from 3.97 to 8.57 and 29.73 to 36.19 per cent per family per annum, it may be due to conversion of agricultural land to non-agricultural sector, it can be seen from table 1 in the 10 kilometres periphery farm income was considerably lower that 53.08 per cent than the 37.62 per cent, it may be due to enhancement of selling habit in sampled households, which got much more amount from that as compared to last five year.

Table 2 Income from different sources Per family per Annum (In Rs.) - North Direction:

\section{Per Family}

\section{Particulars}

\section{Overall}

\begin{tabular}{ccccccccc} 
& \multicolumn{2}{c}{ 10 Kilometers } & \multicolumn{2}{c}{ 20 Kilometers } & \multicolumn{2}{c}{ 30 Kilometers } & & \\
\cline { 2 - 8 } & Before & Present & Before & Present & Before & Present & Before & Present \\
\hline \multirow{2}{*}{ Farm } & 43701.44 & 62880.99 & 48554.2 & 60752.3 & 49586.05 & 144236.9 & $\mathbf{4 7 2 8 0 5 6 . 5 6}$ & $\mathbf{8 9 2 9 0 . 2 3}$ \\
& $(53.08)$ & $(37.62)$ & $(73.30)$ & $(49.67)$ & $(75.90)$ & $(73.79)$ & $\mathbf{( 6 6 . 3 0 )}$ & $\mathbf{( 5 5 . 2 4 )}$ \\
\hline \multirow{2}{*}{ Off Farm } & 1530 & 8730 & 4516 & 22120 & 2435 & 10677 & $\mathbf{2 8 2 7}$ & $\mathbf{1 3 8 4 2 . 3 3}$ \\
& $(1.85)$ & $(5.23)$ & $(6.82)$ & $(18.09)$ & $(3.73)$ & $(5.47)$ & $\mathbf{( 3 . 9 7 )}$ & $\mathbf{( 8 . 5 7 )}$ \\
\hline
\end{tabular}


Effectct of Changes in Land Use on Income and Expenditure Pattern of the Selected Households in

\begin{tabular}{ccccccccc}
\hline & & & & & & & & \\
Non Farm & 37116 & 95520 & 13170 & 39440 & 13315 & 40560 & $\mathbf{2 1 2 0 0 . 3 3}$ & $\mathbf{5 8 5 0 6 . 6 7}$ \\
& $(45.07)$ & $(57.15)$ & $(19.88)$ & $(32.24)$ & $(20.37)$ & $(20.74)$ & $(\mathbf{2 9 . 7 3})$ & $(\mathbf{3 6 . 1 9})$ \\
\hline Overall & $\mathbf{8 2 3 4 7 . 4}$ & $\mathbf{1 6 7 1 3 1}$ & $\mathbf{6 6 2 4 0 . 2}$ & $\mathbf{1 2 2 3 1 2}$ & $\mathbf{6 5 3 3 6 . 1}$ & $\mathbf{1 9 5 4 7 3 . 9}$ & $\mathbf{7 1 3 0 7 . 8 8}$ & $\mathbf{1 6 1 6 3 9 . 2 3}$ \\
\hline
\end{tabular}

Note: Before- 2004-05, present- 2009-10 Figures in parenthesis indicated percentage to total income

Income from different sources Per family per Annum (In Rs.) - South Direction

Income received from farm, off-farm and non-farm activities was given in table 3. Total income received by the households in farm activities was Rs.67427.41 was in before last five year, however at present 76577.06 per family per annum, in south direction of Raipur town. The contribution of farm income to total income was declined from 74.10 to 53.35 per cent at the same time off-farm and non-farm income were increased from 3.04 to 8.95 and 22.83 to 37.80 per cent per family per annum, it may be due to conversion of agricultural land to non-agricultural sector, it can be seen from table 3 in the 10 kilometres periphery farm income was considerably lower that 53.08 per cent than the 37.62 per cent, it may be due to enhancement of selling habit in sampled households, which got much more amount from that as compared to last five year.

Table 3 Income from different sources Per family per Annum (In Rs.) - South Direction Per Family

\begin{tabular}{|c|c|c|c|c|c|c|c|c|}
\hline \multirow{3}{*}{ Particulars } & \multicolumn{6}{|c|}{ Per Family } & \multirow{2}{*}{\multicolumn{2}{|c|}{ Overall }} \\
\hline & \multicolumn{2}{|c|}{10 Kilometers } & \multicolumn{2}{|c|}{20 Kilometers } & \multicolumn{2}{|c|}{30 Kilometers } & & \\
\hline & Before & Present & Before & Present & Before & Present & Before & Present \\
\hline & $\begin{array}{c}47881.20 \\
(75.25) \\
\end{array}$ & $\begin{array}{c}57526.30 \\
(52.89) \\
\end{array}$ & $\begin{array}{c}85271.34 \\
(68.79) \\
\end{array}$ & $\begin{array}{c}106378.67 \\
(50.52) \\
\end{array}$ & $\begin{array}{c}70876.90 \\
(80.38) \\
\end{array}$ & $\begin{array}{c}79397.41 \\
(56.51) \\
\end{array}$ & $\begin{array}{c}67427.41 \\
(74.10) \\
\end{array}$ & $\begin{array}{c}76577.06 \\
(53.35) \\
\end{array}$ \\
\hline & $\begin{array}{c}2435 \\
(3.78) \\
\end{array}$ & 7 & $\begin{array}{c}1530 \\
(1.23) \\
\end{array}$ & $\begin{array}{r}8730 \\
(4.14) \\
\end{array}$ & $\begin{array}{c}4516 \\
(5.00) \\
\end{array}$ & $\begin{array}{l}22 \\
(15 \\
\end{array}$ & $\begin{array}{c}2827 \\
(3.04) \\
\end{array}$ & $\begin{array}{c}13842.33 \\
(8.94) \\
\end{array}$ \\
\hline & $\begin{array}{c}13315 \\
(20.70)\end{array}$ & $\begin{array}{l}40560 \\
(36.21)\end{array}$ & $\begin{array}{l}37116 \\
(29.96)\end{array}$ & $\begin{array}{l}95520 \\
(45.32)\end{array}$ & $\begin{array}{c}13170 \\
(14.60)\end{array}$ & $\begin{array}{c}39440 \\
(27.85)\end{array}$ & $\begin{array}{c}21200.33 \\
(22.83)\end{array}$ & $\begin{array}{c}\mathbf{5 8 5 0 6 . 6 7} \\
(37.80)\end{array}$ \\
\hline Overall & 63631.2 & 108763 & 120716 & 210628.7 & 88562.9 & 140957.4 & 92785.48 & 148926.1 \\
\hline
\end{tabular}

Note: Before- 2004-05, present- 2009-10 Figures in parenthesis indicated percentage to total income

Overall Income from different sources Per family per Annum (In Rs.)

Income received from farm, off-farm and non-farm activities was estimated in Rs. Per family/ annum it is given in table 4. Total income received by the households in farm activities was Rs.114707.97 was in before last five year, however at present 1655867.29 per family per annum. The contribution of farm income to total income was declined from 70.47 to 53.40 per cent at the same time off-farm and non-farm income were increased from 3.48 to 8.92 and 26.05 to 37.68 per cent per family per annum, it may be due to conversion of agricultural land to non-agricultural sector, it can be seen from table 5 at present in the 10 kilometres periphery farm income was considerably lower that 43.65 per cent than the 62.72 per cent, it may be due to enhancement of selling habit in sampled households, which got much more amount from that as compared to last five year.

Table 4 Overall Income from different sources Per family per Annum (In Rs.)

Per Family

\begin{tabular}{|c|c|c|c|c|c|c|c|c|}
\hline \multirow{3}{*}{$\begin{array}{c}\text { Particular } \\
\text { s }\end{array}$} & \multirow{2}{*}{\multicolumn{2}{|c|}{10 Kilometers }} & \multirow{2}{*}{\multicolumn{2}{|c|}{20 Kilometers }} & \multirow{2}{*}{\multicolumn{2}{|c|}{30 Kilometers }} & \multirow{2}{*}{\multicolumn{2}{|c|}{ Overall }} \\
\hline & & & & & & & & \\
\hline & Before & Present & Before & Present & Before & Present & Before & Present \\
\hline & & 120407.7 & 133825.5 & 167130.9 & 120462.9 & 223634.3 & 114707.9 & 165867.2 \\
\hline Farm & $\begin{array}{c}91582.64 \\
(62.72)\end{array}$ & $\begin{array}{c}9 \\
(43.65)\end{array}$ & $\begin{array}{c}4 \\
(70.38)\end{array}$ & $\begin{array}{c}9 \\
(50.20)\end{array}$ & $\begin{array}{c}5 \\
(78.28)\end{array}$ & $\begin{array}{c}1 \\
(66.48)\end{array}$ & $\begin{array}{c}7 \\
(70.47)\end{array}$ & $\begin{array}{c}9 \\
(\mathbf{5 3 . 4 0})\end{array}$ \\
\hline Off $F$ & $\begin{array}{c}3965.00 \\
(2.72)\end{array}$ & $\begin{array}{l}19407 \\
(7.03)\end{array}$ & $\begin{array}{c}6046 \\
(3.18)\end{array}$ & $\begin{array}{l}30850 \\
(9.27)\end{array}$ & $\begin{array}{l}6951 \\
(4.52)\end{array}$ & $\begin{array}{l}32797 \\
(9.74) \\
\end{array}$ & $\begin{array}{c}5654 \\
(3.48)\end{array}$ & $\begin{array}{c}27684.66 \\
(8.92)\end{array}$ \\
\hline Non I & $\begin{array}{c}50431.00 \\
(34.56) \\
\end{array}$ & $\begin{array}{l}136080 \\
(49.32)\end{array}$ & $\begin{array}{l}50286 \\
(26.44) \\
\end{array}$ & $\begin{array}{l}134960 \\
(40.53)\end{array}$ & $\begin{array}{c}26485 \\
(17.20) \\
\end{array}$ & $\begin{array}{l}80000 \\
(23.78) \\
\end{array}$ & $\begin{array}{c}42400.62 \\
(26.05)\end{array}$ & $\begin{array}{c}117013.3 \\
(37.68) \\
\end{array}$ \\
\hline Overall & $\begin{array}{c}145978.6 \\
4 \\
(100) \\
\end{array}$ & $\begin{array}{c}275894.7 \\
9 \\
(100) \\
\end{array}$ & $\begin{array}{c}190157.5 \\
4 \\
(100) \\
\end{array}$ & $\begin{array}{c}332940.9 \\
9 \\
(100) \\
\end{array}$ & $\begin{array}{c}153898.9 \\
5 \\
(100) \\
\end{array}$ & $\begin{array}{c}336431.3 \\
1 \\
(100) \\
\end{array}$ & $\begin{array}{c}162762.5 \\
9 \\
(100) \\
\end{array}$ & $\begin{array}{c}310565.2 \\
5 \\
(100) \\
\end{array}$ \\
\hline
\end{tabular}

Note: Before- 2004-05, present- 2009-10 Figures in parenthesis indicated percentage to total income.

\subsubsection{Overall Expenditure on Food, Non-Food and Agricultural Development of the Sampled Households (Excluding Land Sale)}

An enquiry into the overall consumption and expenditure pattern of the selected households indicted in the table 4.3.1. The overall expenditure on food, non food and agricultural development items was considerably lower Rs. 435698.87 in the before five year however, Rs. 625985.87 per family per annum in the present. 
Overall expenditure on food items was observed 22.72 to 22.43 per cent. At the same time overall expenditure on non-food items was decreased from 38.96 to 26.83 per cent except in the field of health care and education. These shows consciousness of respondents about health care and education as wel. On the other hand expenditure on the Agricultural development, expenses in the Agricultural inputs was increased from 38.42 to 50.74 per cent per family per annum. It was may be due to the agricultural inputs price hike day by day. Increasing Expenditure on the education due to awareness of the people and some special policy intervention by the government with respect to the school shiksha as well as higher education. Price increases of food items constitute a covariate shock, that if it persists in time, its consequences will affect all aspects of the livelihoods.

\begin{tabular}{|c|c|c|c|c|c|c|c|c|}
\hline \multirow{3}{*}{ Particulars } & \multicolumn{6}{|c|}{ Per Family } & \multirow{2}{*}{\multicolumn{2}{|c|}{ Overall }} \\
\hline & \multicolumn{2}{|c|}{10 Kilometers } & \multicolumn{2}{|c|}{20 Kilometers } & \multicolumn{2}{|c|}{30 Kilometers } & & \\
\hline & Before & Present & Before & Present & Before & Present & Before & Present \\
\hline $\begin{array}{l}\text { I. Food } \\
\text { Consuption }\end{array}$ & $\begin{array}{l}100550 \\
(25.78)\end{array}$ & $\begin{array}{c}150464 . \\
8 \\
(29.13) \\
\end{array}$ & $\begin{array}{r}96126.4 \\
(21.77)\end{array}$ & $\begin{array}{c}150338 . \\
4 \\
(22.66) \\
\end{array}$ & $\begin{array}{l}100399 \\
(21.13)\end{array}$ & $\begin{array}{c}152550.4 \\
(21.86)\end{array}$ & $\begin{array}{c}99025.13 \\
(22.73)\end{array}$ & $\begin{array}{l}151117.8 \\
6(22.43)\end{array}$ \\
\hline $\begin{array}{l}\text { II. Non Food } \\
\text { Consuption }\end{array}$ & $\begin{array}{l}134514.8 \\
0(34.49)\end{array}$ & $\begin{array}{c}92482.8 \\
0 \\
(17.91)\end{array}$ & $\begin{array}{l}220016.2 \\
0(49.78)\end{array}$ & $\begin{array}{l}233018 \\
(35.11)\end{array}$ & $\begin{array}{l}159694.2 \\
0(33.61)\end{array}$ & $\begin{array}{l}172011.2 \\
0(24.65)\end{array}$ & $\begin{array}{l}171408.3 \\
9(38.96)\end{array}$ & $\begin{array}{l}165837.3 \\
3(26.83)\end{array}$ \\
\hline $\begin{array}{l}\text { III. } \\
\text { Agricultural } \\
\text { Development } \\
\text { \& } \\
\text { FarmEquipme } \\
\text { nts }\end{array}$ & $\begin{array}{l}154926 \\
(39.73)\end{array}$ & $\begin{array}{l}273546 \\
(52.96)\end{array}$ & $\begin{array}{l}125760 \\
(28.45)\end{array}$ & $\begin{array}{l}280173 \\
(42.23)\end{array}$ & $\begin{array}{l}215110 \\
(45.26)\end{array}$ & $\begin{array}{l}373373 \\
(53.49)\end{array}$ & $\begin{array}{l}165265.3 \\
3(38.42)\end{array}$ & $\begin{array}{l}309030.6 \\
6(50.74)\end{array}$ \\
\hline Overall & $\begin{array}{c}389990.8 \\
(100)\end{array}$ & $\begin{array}{c}516493 . \\
6 \\
(100) \\
\end{array}$ & $\begin{array}{c}441902.6 \\
(100)\end{array}$ & $\begin{array}{c}663529 . \\
4 \\
(100) \\
\end{array}$ & $\begin{array}{c}475203.2 \\
(100)\end{array}$ & $\begin{array}{c}697934.6 \\
(100)\end{array}$ & $\begin{array}{c}435698.8 \\
7 \\
(100) \\
\end{array}$ & $\begin{array}{c}625985.8 \\
7 \\
(100) \\
\end{array}$ \\
\hline
\end{tabular}

Note: Before- 2004-05, present- 2009-10 Figures in parenthesis indicated percentage to total income.

\subsubsection{Overall Expenditure on Food, Non-Food and Agricultural Development of the Sampled Households (Including Land Sale)}

An enquiry into the overall consumption and expenditure pattern of the selected households indicted in the table 4.3.2. The overall expenditure on food, non food and agricultural development items was considerably lower Rs. 483292.09 in the before five year however Rs. 3460003.2 per family per annum at present. Overall expenditure on food items was observed 30.34 to 6.55 per cent. At the same time overall expenditure on nonfood items was increased from 35.46 to 53.80 per cent. On the other hand expenditure on the Agricultural expenses in the Agricultural inputs was decreased from 31.83 to 8.75 per cent per family per annum. It may be due to households were expend maximum share of the land sale income expended on non-Agricultural items like purchasing of bikes means of entertainment and luxurious things and gambling as well. On the contrary after selling of the land the respondents purchase tractor for cultivation and other purposes.

\begin{tabular}{|c|c|c|c|c|c|c|c|c|}
\hline \multirow{3}{*}{ Particulars } & \multicolumn{6}{|c|}{ Per Family } & \multicolumn{2}{|c|}{ Overall } \\
\hline & \multicolumn{2}{|c|}{10 Kilometers } & \multicolumn{2}{|c|}{20 Kilometers } & \multicolumn{2}{|c|}{30 Kilometers } & & \\
\hline & Before & Present & Before & Present & efore & Present & Before & Present \\
\hline $\begin{array}{l}\text { I. Food } \\
\text { Consuption }\end{array}$ & 0550 & $\begin{array}{l}150464 \\
8(3.90)\end{array}$ & $\begin{array}{c}96126 . \\
4 \\
(21.75)\end{array}$ & $\begin{array}{c}150338.4 \\
(3.26)\end{array}$ & & $\begin{array}{c}152550.4 \\
(3.94)\end{array}$ & $\begin{array}{c}146618 . \\
45 \\
(30.34)\end{array}$ & $\begin{array}{c}226676.7 \\
8(6.55)\end{array}$ \\
\hline $\begin{array}{l}\text { II. Non Food } \\
\text { Consuption }\end{array}$ & $\begin{array}{c}134514 . \\
80\end{array}$ & $\begin{array}{c}2139974 \\
.8 \\
(55.46)\end{array}$ & $\begin{array}{c}220016 \\
.2 \\
(49.79)\end{array}$ & $\begin{array}{c}3088657 . \\
87 \\
(67.05)\end{array}$ & $\begin{array}{c}159694 \\
.2 \\
(33.61)\end{array}$ & $\begin{array}{c}2049676 . \\
67 \\
(53.00)\end{array}$ & $\begin{array}{c}171408 . \\
33 \\
(35.46)\end{array}$ & 5. \\
\hline $\begin{array}{l}\text { III. } \\
\text { Agricultural } \\
\text { Development } \\
\text { Farm } \\
\text { Fauinments }\end{array}$ & $\begin{array}{l}154926 \\
(39.73)\end{array}$ & $\begin{array}{c}1568424 \\
.4 \\
(40.64)\end{array}$ & $\begin{array}{l}125760 \\
(28.46)\end{array}$ & $\begin{array}{c}1367835 . \\
29 \\
(29.69)\end{array}$ & $\begin{array}{l}215110 \\
(45.27)\end{array}$ & $\begin{array}{c}1665156 . \\
76 \\
(43.06)\end{array}$ & $\begin{array}{c}165265 . \\
31 \\
(34.20)\end{array}$ & $\begin{array}{c}1371800 . \\
62(39.65)\end{array}$ \\
\hline & $\begin{array}{c}389991 \\
(100)\end{array}$ & $\begin{array}{c}3858864 \\
(100)\end{array}$ & $\begin{array}{c}441902 \\
.6 \\
(100) \\
\end{array}$ & $\begin{array}{c}4606831 . \\
56 \\
(100) \\
\end{array}$ & $\begin{array}{c}475203 \\
.2 \\
(100)\end{array}$ & $\begin{array}{c}3867384 \\
(100)\end{array}$ & $\begin{array}{c}483292 . \\
09 \\
(100)\end{array}$ & $\begin{array}{c}3460003 . \\
2 \\
(100)\end{array}$ \\
\hline
\end{tabular}

Note: Before- 2004-05, present- 2009-10 Figures in parenthesis indicated percentage to total income. 


\section{Conclusion}

The study has revealed that a major shifts of land from the desirable to undesirable land use classes. There has been an increase in the forest, double cropped and gross cropped area in Raipur district as well as double cropped and gross cropped area in Durg and forest area and double cropped area in Chhattisgarh, out of various land-use classes. Cropping intensity has been good in the study area province due to households moving towards the vegetable cultivation after the paddy as well. Non-significant association has been found in the different land-use classes except the double cropped, gross cropped and forest area. Indicating the lack of location specific technological advancements and their respective channelization. Both off-farm and non-farm income has been found maximum contribution of sampled households. After to meet out the land sale income, households expenditure has been found in the non-food items, like purchasing of bikes, other means of entertainment, luxurious things and gambling as well. Major consequences pertaining of land sale i.e. gambling and addiction of alcoholisms, followed by loan repayments, got higher prices, distress sale etc.

\section{References}

[1]. Mahesh, R. (1999) Causes and Consequences of Change in Cropping Pattern: A Location-Specific Study, Discussion Paper No. 11, Kerala Research Programme on Local Level Development Centre for Development Studies Thiruvananthapuram.

[2]. Marothia D.K. (2005) Urbanization in Chhattisgarh Journals of Agricultural Economics Research Review, 19 (2):261-269.

[3]. Bala Brij and S.D. Sharma (2005) Effect on Income and Employment of Diversification and Commercialization of Agriculture in Kullu District of Himachal Pradesh, Agricultural Economics Research Review, 18 (2):261-269.

[4]. Kanda Mohan (2006) Impact of Urbanization In Dharwad District of Karnatka, Agricultural Economics Research Review, 21 (4):161166.

[5]. Socio-Economic Reviews \& District Statistical Abstract in Raipur and Durg district 2005 to 2011. 